\title{
EL DERECHO A LA EDUCACIÓN INTERCULTURAL BILINGÜE DE LA NIÑEZ INDÍGENA EN EL PERÚ: AVANCES Y DESAFÍOS
}

\author{
RIGHT TO INTERCULTURAL BILINGUAL EDUCATION FOR \\ INDIGENOUS CHILDREN IN PERU: PROGRESS AND CHALLENGES
}

Karen Maribel Rebaza Vílchez ${ }^{1}$

\author{
Nuccia Seminario Hurtado ${ }^{2}$ \\ "Manan runasimillapi rimaqtiykuqa \\ ancha kasuwankuchu, kastillanu \\ rimaqtaqa, ichaqa, uyarinku pacha, \\ chaymi ñuqayku iskaynin simitapuni \\ wawaykuq yachananta munayku. (...)
}

No nos hacen caso cuando hablamos en quechua, pero cuando hablan castellano

sí les escuchan de inmediato; por eso queremos que nuestros hijos aprendan ambas lenguas (....)"

Santiesteban et al. Diagnóstico sociolingüístico para el fortalecimiento del quechua en comunidades campesinas de Canchis (Cusco), 2008.

\section{Resumen}

El Perú es un país pluricultural y multilingüe donde habitan 55 pueblos indígenas u originarios (51 pueblos amazónicos y 4 andinos) que hablan un total de 47 lenguas indígenas, según la Base de Datos Oficial de Pueblos Indígenas del Ministerio de Cultura del Perú. Asimismo, de acuerdo al Instituto Nacional de Estadísticas e Informática (INEI), el número de niñas, niños y adolescentes cuya lengua materna es indígena asciende a 2 millones aproximadamente, representando al $8 \%$ de la población nacional.

Esta diversidad representa un desafío para el Estado peruano en la formación educativa de calidad básica y superior. Bajo ese contexto, el presente artículo

\footnotetext{
1 Magister en Derecho Constitucional y Derechos Humanos con estudios concluidos de Maestría en Gestión Pública. Docente de la Facultad de Derecho de la Universidad Femenina del Sagrado Corazón (UNIFÉ).

Correo electrónico: karenrebazav@unife.edu.pe

2 Coordinadora General del Círculo de Estudios en Ambiente y Desarrollo Sostenible (CEADES) de la Universidad Femenina del Sagrado Corazón (UNIFÉ). Estudiante del XI ciclo de la Facultad de Derecho de dicha casa superior de estudios.

Correo electrónico: nucciaseminarioh@unife.edu.pe
} 
tiene como objetivo analizar el tratamiento jurídico, avances estatales y desafíos en la garantía del derecho a la educación intercultural bilingüe de la niñez indígena peruana.

Palabra clave: Derechos humanos, derecho constitucional, derecho internacional público, derechos de los pueblos indígenas, derechos económicos, sociales y culturales, derechos de los niños, derecho a la educación intercultural bilingüe y políticas públicas.

\section{Abstract}

Peru is a pluricultural and multilingual country inhabited by 55 indigenous or indigenous peoples (51 Amazonian and 4 Andean peoples) who speak a total of 47 indigenous languages, according to the Official Database of Indigenous Peoples of the Ministry of Culture of Peru. Moreover, according to the National Institute of Statistics and Informatics (INEI), the number of children and adolescents whose mother tongue is indigenous amounts to approximately 2 million, representing 8\% of the national population.

This diversity represents a challenge for the Peruvian State in the educational formation of basic and superior quality. In this context, this article aims to analyze the legal treatment, state advances and challenges in guaranteeing the right to bilingual intercultural education of Peruvian indigenous children.

Keywords: Human rights, constitutional law, public international law, indigenous people rights, economic, social and cultural rights, children rights, bilingual intercultural education right and public policies.

\section{INTRODUCCIÓN}

La riqueza cultural en nuestro país debe ser abordada en el plano educativo a través de la implementación de medidas legislativas y políticas públicas que respondan a los desafíos que de ella provienen.

La educación intercultural bilingüe, orientada particularmente a la atención de los estudiantes de pueblos originarios, garantiza la equidad educativa en el territorio nacional, y con ello, el ofrecimiento de servicios que respondan a las características y necesidades educativas de todos los peruanos.

En los últimos años se han ido desarrollando importantes iniciativas legislativas y políticas públicas en la materia, teniendo en cuenta ello, 
en el presente artículo analizaremos la vigencia efectiva del derecho a la educación intercultural bilingüe de la niñez indígena desde el ámbito normativo interno e internacional para luego identificar los avances y retos del Estado peruano en la materia.

\section{LA DIVERSIDAD CULTURAL Y LINGÜÍSTICA EN EL PERÚ}

El Perú es un país pluricultural y multilingüe porque en sus espacios geográficos existen colectividades que poseen una variedad de culturas y lenguas. Esta diversidad es reconocida como un derecho fundamental de orden constitucional en el artículo 2, inciso 19 de la Carta Magna vigente ${ }^{3}$, que protege desde todas las aristas la identidad cultural, etnolingüística, en especial el derecho de minorías, denominado "pueblos indígenas".

Dicha denominación es relativamente reciente. Los pueblos indígenas o también conocidos como "pueblos originarios" son descendientes de la población $\mathrm{u}$ ocupantes originales de tierras antes que fueran conquistadas por otros, constituyéndose así como sujetos de derecho al ser destinarios de derechos, deberes y obligaciones.

El Convenio 169 de la Organización Internacional del Trabajo (OIT) en su artículo 1 establece los siguientes elementos para identificar un pueblo indígena:

1. Son pueblos anteriores a los estados y tienen continuidad histórica.

2. Sus ancestros habitaron el mismo lugar.

3. Tienen sus propias instituciones culturales, sociales y económicas.

4. Tienen conciencia de sí mismos como comunidad indígena.

En la legislación peruana, por su parte, son conceptualizados como "aquellos que se autorreconocen como tales, mantienen una cultura propia, se encuentran en posesión de un área de tierra, forman parte del Estado peruano conforme a la Constitución. En estos se incluye a los pueblos indígenas en situación de aislamiento o en situación de contacto inicial ${ }^{4 \prime}$.

Ahora bien, la lengua o idioma es una institución sociocultural que expresa la identidad de un pueblo, ya que es un referente de su cosmovisión

Constitución Política del Perú. (1993). Artículo 2, inciso 19.- Toda persona tiene derecho a su identidad étnica y cultural. El Estado reconoce y protege la pluralidad étnica y cultural de la Nación.

4 Ley para la protección de pueblos indígenas u originarios en situación de aislamiento y en situación de contacto inicial. Ley $\mathrm{N}^{\circ} 28736$ de 2006. Literal a), Art. 1. 
y permite la transmisión de conocimientos. La lengua permite comprobar el criterio objetivo de instituciones distintivas y la continuidad histórica, en los casos que la lengua sea originaria (Ministerio de Cultura, 2014, p. 30). En ese sentido, según Miguel León Portilla "las lenguas originarias en la vida de los pueblos indígenas son consideradas como el inventario de cultura, por eso cuando muere alguna es una verdadera tragedia. En ese momento dejan de irse canciones, plegarias y vivencias. Cuando muere una lengua la humanidad se empobrece ${ }^{5 \prime \prime}$.

Como podemos observar, garantizar la identidad cultural lingüística es indispensable para el desarrollo progresivo de los derechos de los pueblos indígenas. Según el Ministerio de Cultura, en el Perú predominan cuarenta y siete lenguas originarias, de las cuales en la región selva se hablan alrededor de cuarenta y tres, mientras que en la región sierra cuatro. Ellas son catalogadas como una "riqueza lingüística y cultural" que la Constitución Política del Perú en su artículo $48^{\circ 6}$ y la Ley $\mathrm{N}^{\circ} 27935$, "Ley que regula el uso, preservación, desarrollo, fomento y recuperación de las lenguas originarias" protegen y reconocen ${ }^{7}$.

Es importante el uso de nuestras lenguas y su revalorización porque forman parte de la identidad de nuestros pueblos y son un vehículo de transmisión de la cultura. Cada expresión y concepto en nuestras lenguas encierra detrás miles de años de conocimiento que se han ido formando, de manera de sentir, ver y recrear el mundo que nos rodea; en ese sentido, es importante seguir utilizando nuestras lenguas originarias porque son una herencia de nuestros antepasados ${ }^{8}$.

En el Perú hasta la fecha han sido registradas cuarenta y siete (47) lenguas indígenas, las cuales son habladas por 4 millones de personas, aproximadamente. Tenemos 4 lenguas en los andes y 43 lenguas en la zona amazónica9 ${ }^{9}$ Según las estadísticas del Ministerio de Educación (MINEDU), en el Perú las lenguas originarias predominantes son: 1) achuar, 2) aimara, 3) amahuaca, 4) arabela, 5) ashaninka, 6) awajún, 7) bora, 8) capanahua, 9)

León-Portilla, Miguel. Discurso en el encuentro «Telar de voces: Literatura en Lenguas Mexicanas», en Informe Defensorial N ${ }^{\circ} 174$ "Educación Intercultural Bilingüe hacia el 2021. Una política de Estado imprescindible para el desarrollo de los pueblos indígenas", elaborado por el Programa de Pueblos Indígenas de la Adjuntía del Medio Ambiente, Servicios Públicos y Pueblos Indígenas de la Defensoría del Pueblo.

6 Constitución Política del Perú. (1993). Artículo 48.- Son idiomas oficiales el castellano y, en las zonas donde predominen, también lo son el quechua, el aimara y las demás lenguas aborígenes, según la ley.

Ministerio de Cultura. 10 cosas que debes saber de las lenguas indígenas peruanas y sus hablantes, Recuperado de: http://www.cultura.gob.pe/sites/default/files/paginternas/tablaarchivos/2013/05/10cosasquedebessabersobrelenguasindigenas.pdf

8 Vídeo "Promoviendo la diversidad lingüística" - Ministerio de Cultura. Recuperado de: https://www.youtube.com/ watch? $\mathrm{v}=\mathrm{TxGqd74N1 \textrm {NI }}$

Vídeo "Perú país de muchas lenguas" - Ministerio de Cultura. Recuperado de: https://www.youtube.com/watch?$\mathrm{v}=9 \mathrm{ZCUzs} 2 \mathrm{XiJ} 4$ 
cashinahua, 10) cauqui, 11) chamicuro, 12) ese eja, 13) harakbut, 14) iñapari, 15) iquitu, 16) isconahua, 17) jaqaru, 18) kakataibo 19) kakinte (caquinte), 20) kandozi-chapra, 21) kukama-kukamiria, 22) madija (culina), 23) maijuna, 24) matsigenka, 25) matses, 26) muniche, 27) murui-muinani, 28) nanti, 29) nomatsigenga, 30) ocaina, 31) omagua, 32) quechua, 33) resígaro, 34) secoya, 35) sharanahua, 36) shawi, 37) shipibo-konibo 38) shiwilu, 39) taushiro, 40) tikuna (ticuna), 41) urarina, 42) wampis, 43) yagua, 44) yaminahua, 45) yanesha, 46) yine y 47) yora. ${ }^{10}$

Asimismo, según las estadísticas del CENSO de 2017, el 17\% de la población peruana tenía como lengua materna una lengua originaria, eso significa que más de 5 millones de peruanos tienen como lengua materna otra que no es el castellano y se encuentra predominantemente en Lima Metropolitana $^{11}$. Bajo ese contexto, consideramos que el Estado Peruano necesita brindar a los pueblos indígenas un tratamiento jurídico especial para su protección.

\section{DERECHO A LA EDUCACIÓN INTERCULTURAL BILINGÜE DE LA NIÑEZ INDÍGENA}

Para definir el derecho a la educación intercultural bilingüe (EIB), consideramos importante desglosar los conceptos -derecho a la educación-, -derecho a la identidad colectiva- y -derechos lingüísticos.

Según el Tribunal Constitucional Peruano el derecho a la educación "es un derecho fundamental intrínseco y, a la vez, un medio indispensable para la plena realización de otros derechos fundamentales, por cuanto permite al ciudadano participar plenamente en la vida social y política en sus comunidades"12, es decir, es un derecho de empoderamiento para participar plenamente en la sociedad. Bajo esa misma línea, el destacado constitucionalista García Toma (2008) expresó que "el derecho fundamental a la educación garantiza a toda persona el interés jurídicamente protegido de recibir una formación que tiene por finalidad su desarrollo integral y la promoción del conocimiento (p.380).

Asimismo, el derecho a la identidad colectiva puede ser definido como el conjunto de rasgos afines de una determinada comunidad que hace que se diferencia de otro, pues, dichos rasgos tienen que ver con

\footnotetext{
10 Ministerio de Educación. Documento Nacional de Lenguas Originarias del Perú. Recuperado de: http://www2. minedu.gob.pe/filesogecop/DNL-version\%20final\%20WEB.pdf

11 Centro de Estudios Constitucionales. I Seminario de Derechos Lingüísticos y Justicia Constitucional. Ponencia de: Elena Antonia Burga Cabrera, Viceministra de Interculturalidad de la República del Perú, 20 de junio de 2018.

12 STC. Expediente $\mathrm{N}^{\circ} 00091-2005-\mathrm{PA} / \mathrm{TC}$, fundamento $6 \mathrm{~A}$.
} 
las costumbres y tradiciones, con ideas, con valores, con actitudes, con el idioma, entre otros. Los derechos lingüísticos, por su parte, son los derechos fundamentales y colectivos que facultan a la persona a usar su lengua materna en todos los espacios sociales. Esto implica desarrollar su vida personal, social, educativa, política y profesional en su propia lengua; recibir atención de los organismos públicos y pertenecer a una comunidad lingüística reconocida y respetada ${ }^{13}{ }^{\prime \prime}$.

En relación a ello, el Tribunal Constitucional Peruano expresa que "los derechos lingüísticos y su relación con el accionar del Estado son abordados por la Constitución, cuando menos, desde una doble perspectiva. De un lado, se encuentra el derecho de cada miembro de una comunidad lingüística a comunicarse en su propio idioma con cualquier autoridad en cualquier lugar de la República (...)"14. Al respecto, Ordoñez (2013) señala que "el derecho a la educación intercultural bilingüe (EIB) es una manifestación constitucional del derecho a la identidad cultural cuya protección la encontramos consagrada a nivel nacional como internacional" (p.87).

Seguidamente Abarca (2015) señala que "la Educación Intercultural Bilingüe (EIB) es un modelo educativo que ha intentado dar respuesta a la formación de niños y niñas indígenas y/o migrantes, que sustentan diversidad cultural, étnica y lingüística, con el fin de favorecer la identidad individual, como también contribuir a la conformación de identidades nacionales en las cuales conviven ciudadanos de origen diverso" (p.3) ; y su objetivo es "el desarrollo de la competencia intercultural- bilingüe en los educandos para que esto contribuya a una educación justa para la niñez a procesos de democratización y equidad social (Zavala y Córdova, 2003, p.15).

Bajo ese orden de ideas, podemos señalar que el derecho a la educación intercultural bilingüe es un derecho fundamental de orden constitucional de carácter colectivo porque se le atribuye a un determinado grupo denominado "pueblos indígenas". Asimismo, se constituye como la seguridad de continuidad en dos vertientes: en un sentido biológico, pues asegura la continuidad del grupo; y en un sentido social y cultural, pues se cifra en ellos la continuidad de la cultura. Por ello existe el compromiso del Estado para proteger estos dos aspectos de la niñez, ya que son sujetos principales de la educación"15.

13 Ministerio de Cultura. Tríptico de Traductores e intérpretes de Lenguas Indígenas. Recuperado de: http://www. cultura.gob.pe/sites/default/files/Ttriptico.pdf

$14 \quad$ STC. Expediente $N^{\circ}$ 00889-2017-PA/TC, fundamento 8.

15 Universidad Nacional Mayor de San Marcos. Taller Internacional sobre Asistencia Técnica en Interculturalidad a Instituciones Educativas de Lima Metropolitana, ponencia de Gustavo Luis Fonseca, tema: «Nuestra diversidad de lenguas y culturas para el desarrollo de la Interculturalidad-pautas para la elaboración de un diagnóstico lingüístico y sociocultural», noviembre 2017 . 
Es así que la EIB se caracteriza como democrática y popular. Es democrática porque da igualdad de oportunidades a la población de lengua y cultura nativas. Es popular porque está orientada a promover la participación de comunidades de lengua y culturas nativas. (Soto, 2008, p.16).

\section{TRATAMIENTO JURÍDICO INTERNACIONAL}

Los instrumentos jurídicos internacionales marcaron una transcendencia fundamental para la protección del derecho a la educación intercultural bilingüe, por ello en las siguientes líneas abordaremos el tratamiento jurídico de esta temática a nivel universal e interamericano.

\subsection{Sistema Universal}

La Convención sobre los Derechos del Niño ${ }^{16}$ ratificada por 195 Estados durante los años 1989 a 1992, tiene el propósito de proteger internacionalmente el goce de los derechos de los niños, niñas y adolescentes. Según Romero (2006) manifiesta que "para los efectos de dicha Convención, se entendió por niño a todo ser humano menor de 18 años de edad, salvo en virtud de la ley que le sea aplicable, haya alcanzado antes, la mayoría de edad (p. 197). El derecho a la educación está expreso en dicho instrumento jurídico internacional, en sus artículos $28^{\circ}$ y $30^{\circ}$, considerando a la educación como un derecho inherente del niño, imprescindible para el desarrollo de sus actitudes, habilidades y capacidades mentales en el ejercicio de su formación mental, física y educativa.

Asimismo, el Convenio 169 de la Organización Internacional del Trabajo (OIT) sobre sobre Pueblos Indígenas y Tribales $(1989)^{17}$, reconocido como el principal instrumento de los derechos de pueblos indígenas, en sus artículos $27^{\circ}$ y $28^{\circ}$ reconocen el fomento de la educación indígena. Adicionalmente, en su artículo 1, inciso b) señala que el Convenio se aplica a: “(...) los pueblos en países independientes, considerados indígenas por el hecho de descender de poblaciones que habitaban en el país o en una región geográfica a la que pertenece el país en la época de la conquista o la colonización o del establecimiento de las actuales fronteras estatales y que, cualquiera que sea su situación jurídica, conservan todas sus propias instituciones sociales, económicas, culturales y políticas, o parte de ellas"18.

16 Convención sobre los Derechos del Niño, suscrita por Perú el 26 de enero de 1990 y aprobada mediante Resolución Legislativa № 25278 el 3 de agosto de 1990 por el Congreso de la República del Perú.

17 Convenio $N^{\circ} 169$, Organización Internacional del Trabajo (OIT) sobre pueblos y tribales en países independientes. Firmado en Ginebra el 27 de junio de 1989, aprobada por Perú mediante Resolución Legislativa № 26253.

18 Instituto de Democracia y Derechos Humanos de la Pontificia Universidad Católica del Perú y Fundación René Cassin. VI Curso Internacional de Actualización: Sistema Interamericano de Derechos Humanos y Políticas Públicas a favor de Grupos en situación de Vulnerabilidad. Ponencia de: Daniel Cerqueira, Módulo VII: «Políticas públicas a favor de Pueblos Indígenas y poblaciones afrodescendientes, basadas en un enfoque de DDHH desde el SIDH», marzo 2018. 
Además, la Declaración de las Naciones Unidas sobre los derechos de los pueblos indígenas (2007) ${ }^{19}$, en su artículo $14^{\circ}$ señala lo siguiente: "1. Los pueblos indígenas tienen derecho a establecer y controlar sus sistemas e instituciones docentes que impartan educación en sus propios idiomas, en consonancia con sus métodos culturales de enseñanza y aprendizaje. 2. Los indígenas, en particular los niños, tienen derecho a todos los niveles y formas de educación del Estado sin discriminación. 3. Los Estados adoptarán medidas eficaces, conjuntamente con los pueblos indígenas, para que las personas indígenas, en particular los niños, incluidos los que viven fuera de sus comunidades, tengan acceso, cuando sea posible, a la educación en su propia cultura y en su propio idioma". Como podemos observar, esta Declaración resalta la importancia de la adecuada formación educativa de los pueblos indígenas.

Finalmente, el Pacto Internacional de Derechos Económicos, Sociales y Culturales $(1976)^{20}$, conocido como PIDESC, en su artículo $13^{\circ}$ establece la obligación de educación universal y gratuita, considerándola una obligación de resultado. Asimismo, el Primer Protocolo Facultativo del PIDESC, reconoce la competencia de su Comité para recibir y considerar comunicaciones de individuos (que se hallen bajo jurisdicción de un Estado parte del PIDESC) que aleguen ser víctimas de una violación del citado Pacto Internacional.

Respecto a este punto, es importante precisar que el Estado Peruano no ha ratificado aún dicho Protocolo. En ese sentido, el Comité del PIDESC no tiene competencia para recibir comunicaciones de particulares que aleguen la vulneración del derecho a la educación.

\subsection{Sistema Interamericano}

La Convención Americana de Derechos Humanos ${ }^{21}$ o también conocida como Pacto San José (1969), en su artículo $26^{\circ}$ establece la obligatoriedad de los Estados partes para garantizar los derechos económicos, sociales y culturales, como es el caso del derecho a la educación. Además, la Declaración Americana sobre Derechos de los Pueblos Indígenas $^{22}$ (2016), en su artículo $15^{\circ} .1$ establece que "los pueblos y personas indígenas, en particular los niños

19 Declaración de las Naciones Unidas sobre Pueblos Indígenas, adoptada y proclamada por la Resolución de la Asamblea General 217 A. el 10 de diciembre de 1948.

20 Pacto Internacional de Derechos Económicos, Sociales y Culturales. Adoptado y abierto a la firma, ratificación y adhesión por la Asamblea General en su resolución 2200 A (XXI), de 16 de diciembre de 1966, por el Gobierno de la República del Perú mediante Decreto Ley N²2129.

21 Convención Americana sobre Derechos Humanos aprobada en San José, Costa Rica, 7 al 22 de noviembre de 1969 y aprobada por el Gobierno de la República del Perú mediante Decreto Ley N²2231, el 27 de julio de 1977.

22 Declaración Americana sobre Derechos de los Pueblos Indígenas, aprobada en la segunda sesión plenaria, celebrada el 14 de junio de 2016. 
y niñas indígenas, tienen derecho a todos los niveles y formas de educación, sin discriminación".

Por otrolado, es preciso indicar que el Informe Consultivo dela Comisión Interamericana de Derechos Humanos (CIDH) de fecha 30 de noviembre de 2017, reiteró las obligaciones estatales de los Estados partes para garantizar derechos de los niños, niñas y adolescentes. Sobre el particular, expresó que "la perspectiva intercultural supone un respeto por las diferencias, reconoce y respeta el derecho a la diversidad y fomenta la interacción entre culturas de una forma equitativa, donde se concibe que ningún grupo cultural se encuentre por encima del otro, y reconoce y valora los aportes de todos ellos en la sociedad (...)" (p. 150, fundamento 384).

Además, la Corte Interamericana de Derechos Humanos (Corte IDH) determinó en el caso Comunidad Xákmok Kásek vs. Paraguay que: "la identificación de la Comunidad, desde su nombre hasta su composición, es un hecho histórico social que hace parte de su autonomía (...). Por tanto, el Estado debe limitarse a respetar las determinaciones que en este sentido presente la Comunidad, es decir, la forma cómo ésta se auto-identifique" 23

En esa misma línea, la Corte IDH en el caso Pueblo indígena Kichwa de Sarayaku vs. Ecuador señaló que: “(...) el Estado debe adoptar las medidas legislativas, administrativas o de otra índole que sean necesarias para poner plenamente en marcha y hacer efectivo, en un plazo razonable, el derecho a la consulta previa de los pueblos y comunidades indígenas y tribales y modificar aquellas que impidan su pleno y libre ejercicio, para lo cual debe asegurar la participación de las propias comunidades"24, es decir, en el caso de la educación intercultural bilingüe se considera fundamental la participación de la comunidad indígena para el desarrollo de las políticas públicas, asimismo para su desarrollo como personas humanas en el ámbito educativo, cultural y lingüístico.

\section{TRATAMIENTO JURÍDICO INTERNO}

En el ordenamiento peruano, la educación intercultural bilingüe asume dos vertientes -interculturalidad- y -lengua originaria- desde una concepción social, antropológica y jurídica. A propósito de ello, a continuación incidiremos en la normatividad interna que protege estas dos vertientes.

\footnotetext{
23 Corte Interamericana de Derechos Humanos. Caso Comunidad Indígena Xákmok Kásek vs. Paraguay, sentencia de 24 de agosto de 2010 (fondo, reparaciones y costas), fundamento 37.

24 Corte Interamericana de Derechos Humanos. caso Pueblo indígena Kichwa de Sarayaku vs. Ecuador, sentencia 27 de junio de 2012 (fondo, reparaciones y costas), fundamento 301.
} 
La Constitución Política del Perú vigente, en su artículo $17^{\circ}$ reconoce la obligatoriedad del Estado de fomentar y garantizar la educación. Respecto a ello, el Tribunal Constitucional Peruano, en el expediente 008532015-PA/TC, expresó que la educación permite a las personas adquirir lo necesario para convertirse en ciudadanos e insertarse en la sociedad y por ello nos encontramos ante un mandato rectamente vinculante para el Estado Peruano ${ }^{25}$.

Por su parte, el Código de los niños, niñas y adolescentes, en su artículo 14, expresa las obligaciones del Estado Peruano para garantizar la gratuidad pública de la enseñanza para quienes tienen limitaciones económicas, y en el inciso d) de su artículo 15, señala que la educación básica en las zonas donde haya predominancia de una lengua originaria, debe garantizar el respeto a los padres, a la propia identidad cultural, al idioma, a los valores nacionales y los valores de los pueblos indígenas.

Asimismo, la Ley $N^{\circ}$ 28044, Ley General de Educación, promulgada el 17 de julio de 2003, establece en su artículo 2, que "la educación es un derecho fundamental de la persona y de la sociedad. El Estado garantiza el ejercicio del derecho a una educación integral y de calidad para todos y la universalización de la Educación Básica" y con ello se refuerza la obligatoriedad estatal de brindar a todos una educación inclusiva de calidad. De forma particular, la Ley $\mathrm{N}^{\circ} 27818$, Ley Educación Bilingüe Intercultural, promulgada 22 de julio de 2002, garantiza la vigencia efectiva del derecho a la educación desde una cosmovisión indígena, perseverando su interculturalidad y lengua originaria.

Seguido a ello, la Ley $\mathrm{N}^{\circ} 29735$, Ley que regula el uso, preservación, desarrollo, fomento y recuperación de las lenguas originarias, promulgada en julio del 2011, también conocido como Ley de los Derechos Lingüísticos, en el inciso h) de su artículo 4, señala que toda persona tiene derecho a recibir educación en su lengua materna y en su propia cultura bajo una visión intercultural. Asimismo, su Reglamento, aprobado por Decreto Supremo 004-2016-MC, señala en su artículo $33^{\circ}$ y $35^{\circ}$ lo siguiente:

\section{"Artículo 33.- La Educación Intercultural Bilingüe \\ 33.1. La Educación Intercultural Bilingüe (EIB) se imparte en todas las etapas, niveles y modalidades del sistema educativo, y tiene como destinatarios a los miembros de los pueblos indígenas u originarios que tienen una lengua indígena u originaria como lengua materna o lengua de herencia.}

25 STC expediente $\mathrm{N}^{\circ}$ 00853-2015-PA/TC fundamento 67. 
33.2. El Ministerio de Educación diseña la Política Nacional de Educación Intercultural y Educación Intercultural Bilingüe, el Plan Nacional de Educación Intercultural Bilingüe, el modelo de servicio de Educación Intercultural Bilingüe con diversas formas de atención, y todas las herramientas pedagógicas y de gestión necesarias, a efectos de garantizar la enseñanza de las lenguas indígenas u originarias en el marco de una propuesta pedagógica cultural y lingüísticamente pertinente.

Artículo 35.- Alfabetización intercultural

El Ministerio de Educación es el ente encargado de emitir las normas necesarias para el correcto desarrollo de los Programas de Alfabetización Intercultural. Los temas principales a ser desarrollados son los siguientes:

1. Orientaciones para que el Programa tome en cuenta las características socioculturales y lingüísticas de sus beneficiarios/as.

2. Elaboración de los materiales educativos del Programa de Alfabetización a partir de los conocimientos y actividades socioproductivos de los/las beneficiarios/as y sus pueblos en la lengua indigena u originaria de los mismos.

3. Estrategias de fortalecimiento de capacidades a los/las docentes y facilitadores/as del Programa de Alfabetización con un enfoque de Educación Intercultural Bilingüe.

4. Sistema de información con enfoque intercultural bilingüe de los/las beneficiarios/as del Programa.

5. Mecanismos para asegurar la participación de las organizaciones representativas indigenas en la implementación de los programas de alfabetización en los ámbitos interculturales bilingües.

\section{Otros datos de importancia en la materia.}

En esa misma línea, el artículo $3^{\circ}$ de la Ley $\mathrm{N}^{\circ} 29785$, Ley del derecho a la consulta previa a los pueblos indígenas $\mathfrak{u}$ originarios ${ }^{26}$, señala que "la finalidad de la consulta es alcanzar un acuerdo o consentimiento entre el Estado y los pueblos indígenas u originarios respecto a la medida legislativa o administrativa que les afecten directamente, a través de un diálogo intercultural que garantice su inclusión en los procesos de toma de decisión del Estado y la adopción de medidas respetuosas de sus derechos colectivos".

26 Reglamento aprobado por Decreto Supremo Nº01-2012- MC 
Entonces, de ambos dispositivos legales podemos colegir que el Estado peruano considera crucial su comunicación con los pueblos indígenas, particularmente cuando se debe tomar una decisión que repercute en su comunidad. En ese contexto, consideramos que la educación intercultural bilingüe para la participación indígena es fundamental.

Respecto al desarrollo jurisprudencial del derecho a la educación, el Tribunal Constitucional en el expediente $\mathrm{N}^{\circ} 00853-2015-\mathrm{PA} / \mathrm{TC}$ estableció que "el artículo 13 de la Constitución establece que la educación tiene como finalidad el desarrollo integral de la persona humana, y su artículo 14 estipula que la educación promueve el conocimiento, el aprendizaje y la práctica de las humanidades, la ciencia, la técnica, las artes, la educación física y el deporte. En líneas generales, prepara para la vida, el trabajo y fomenta la solidaridad"27.

Asimismo, en relación al derecho a la identidad cultural, señaló que es "la facultad que tiene la persona que pertenece a un grupo étnico determinado de ser respetada en las costumbres y tradiciones propias de la etnia a la cual pertenece, evitándose con ello que desaparezca la singularidad de tal grupo. Esto es, el derecho de la etnia a existir, de conformidad con la herencia de los valores de sus ancestros y bajo símbolos e instituciones que diferencian a tal comunidad de las demás" ${ }^{28}$. Y este análisis, sin duda, tiene relación directa con en el artículo 2, inciso 1 de la Carta Magna vigente, que señala que toda persona tiene derecho a la igualdad ante la ley.

Por otro lado, en relación a los derechos lingüísticos, el Tribunal Constitucional en el expediente 00889-2017-PA/TC, expresó que "la virtualidad máxima de la dimensión colectiva del derecho al uso de una lengua originaria, se alcanza cuando ella es predominante en una zona geográfica del país (entendiéndose como zona de predomino el unidad mínima, la provincia o la región, de acuerdo a lo establecido en el artículo 7 de la ley de lenguas), pues en ese caso, dicha lengua, debe ser oficial en la referida zona. Ello se encuentra reconocido en el artículo $48^{\circ}$ de la Constitución" ${ }^{\prime 29}$. En relación a ello, el artículo $48^{\circ}$ de la Constitución Política vigente, señala que "son idiomas oficiales el castellano y, en las zonas donde predominen, también lo son el quechua, el aimara y las demás lenguas aborígenes, según la ley".

Respecto a esta reciente sentencia, se debe destacar que desarrolla el derecho al idioma propio, enfocando desde dos vertientes: el derecho

\footnotetext{
STC expediente $\mathrm{N}^{\circ} 00853-2015-\mathrm{PA} / \mathrm{TC}$, fundamento 9 .

STC expediente $\mathrm{N}^{\circ}$ 0022-2009-PI/TC, fundamento 5 .

STC expediente $\mathrm{N}^{\circ}$ 00889-2017-PA/TC, fundamento 9.
} 
al habla de una lengua distinta al castellano y el derecho de usar la lengua en donde predominen las lenguas originarias, establecidos en el inciso 19 del artículo 2 y artículo 48 de la Constitución Política del Perú, respectivamente.

El reconocimiento constitucional del derecho a la educación intercultural bilingüe en la niñez indígena constituye un importante avance en el tratamiento jurídico interno, lo que ayudará a que los niños indígenas reciban una educación de calidad y puedan difundir su cultura y lengua, pues, según el Ministerio de Educación (2013) “la educación peruana contribuirá a lograrlo en la medida que esta educación se caracterice por ser bilingüe por lo menos para quienes poseen el privilegio de tener como lengua materna una lengua autóctona e intercultural." (p.89)

Entre otros instrumentos jurídicos importantes, cabe destacar la Resolución Suprema N ${ }^{\circ}$ 001-2007-ED, que aprobó el "Proyecto Educativo Nacional al 2021: La Educación que queremos para el Perú", el Decreto Supremo 006-2016-MINEDU, que aprobó la "Política Sectorial de Educación Intercultural y Educación Intercultural Bilingüe", y la Resolución Ministerial No 629-2016-MINEDU, que aprueba el "Plan Nacional de Educación Intercultural Bilingüe hacia el 2021", ya que los tres instrumentos tienen como objetivo incorporar la visión y conocimiento indígena en las respectivas estrategias educativas y metodológicas al "establecer la interculturalidad como clave de la educación, siempre relacionado con el desarrollo de la identidad como ciudadano". (Gonzáles, 2015, p. 388)

A pesar de este importante avance en materia de políticas públicas, la existencia de brechas hacia la promoción de la educación intercultural bilingüe en la niñez indígena sigue siendo un reto para el Gobierno peruano, puesto que se espera lograr garantizar la vigencia efectiva de este derecho mediante docentes debidamente capacitados ${ }^{30}$.

En dicho contexto, en el año 2017 se aprobó la Resolución Directoral N001-2017-MINEDU/VMGP/DIGEIBIRA, el cual “establece disposiciones para acreditar el dominio de la lengua originaria y de la cultura local en el marco de los concursos públicos de ingreso a la carrera pública magisterial"; sin embargo, a la fecha, los sectores concernidos no han informado acerca de los resultados obtenidos de su puesta en práctica.

DIGEBIRA. Procesos de la Educación Intercultural Bilingüe. Recuperado de: https://sites.google.com/site/gestiondigeibira/-registro-nacional-de-docentes-bilinguees-en-lenguas-originarias-2018-actualizacion/02-resultados-de-la-evaluacion-2017 


\section{LEGISLACIÓN COMPARADA}

\subsection{Bolivia}

El Estado de Bolivia, en el artículo $1^{\circ}$ de su Carta Magna vigente ${ }^{31}$ expresa que "Bolivia se constituye en un Estado Unitario Social de Derecho Plurinacional Comunitario, libre, independiente, soberano, democrático, intercultural, descentralizado y con autonomías. Bolivia se funda en la pluralidad y el pluralismo político, económico, jurídico, cultural y lingüístico, dentro del proceso integrador del país", reconociendo la diversidad cultural que predomina en su territorio; asimismo, en su artículo $5^{\circ}$ reconoce los la diversidad lingüística señalando que "son idiomas oficiales del Estado el castellano y todos los idiomas de las naciones y pueblos indígena originario campesinos, que son el aymara, araona, baure, bésiro, canichana, cavineño, cayubaba, chácobo, chimán, ese ejja, guaraní, guarasu'we, guarayu, itonama, leco, machajuyai-kallawaya, machineri, maropa, mojeño-trinitario, mojeño-ignaciano, moré, mosetén, movima, pacawara, puquina, quechua, sirionó, tacana, tapiete, toromona, uruchipaya, weenhayek, yaminawa, yuki, yuracaré y zamuco".

En relación a ello, Godoy (2015) manifestó que en "Bolivia se habla más de una treintena de lenguas ya que, junto con el quechua, el aymara y el español, que son mayoritarias en el Altiplano y las zonas centrales, en las Tierras Bajas del oriente se puede escuchar una gran diversidad de lenguas de los pueblos guaraníes y amazónicos." (p.1)

Asimismo, el 7 de julio de 1994, Bolivia aprobó la Ley N¹565, Ley de Reforma Educativa, la cual instauró la educación intercultural bilingüe en su disposición normativa interna. El inciso 5, artículo 1) de dicha Ley expresa que la educación boliviana es "intercultural y bilingüe, porque asume la heterogeneidad socio-cultural del país en un ambiente de respeto entre todos los bolivianos, hombres y mujeres", marcando un hito histórico en materia lingüística, ya que a raíz de esta normativa se oficializaba en el sector educativo las lenguas quechua, aymara y guaraní; bajo esa misma línea, en el inciso 5 de su artículo $3^{\circ}$, señala que son objetivos principales del Estado Plurinacional Boliviano "construir un sistema educativo intercultural y participativo que posibilite el acceso de todos los bolivianos a la educación, sin discriminación alguna".

El Tribunal Constitucional Plurinacional Boliviano en el Expediente N09520-2014-20-CEA enfatizó que "el modelo de Estado reconoce la existencia de naciones y pueblos indígena originario campesinos (NPIOC); fundamentándose, en el respeto a la pluralidad y el pluralismo, en diferentes

\footnotetext{
Constitución Política del Estado Boliviano, en vigor desde el 7 de febrero de 2009.
} 
ámbitos como el político, económico, jurídico, cultural y lingüístico, en un escenario de convergencia del proceso de construcción del Estado Plurinacional" 32 , de esa manera el Estado boliviano reconoce en su Carta Magna vigente la diversidad cultural y lingüística.

\subsection{Colombia}

La República de Colombia, a través de su Constitución Política de $1991^{33}$, se reconoce como un Estado pluricultural y plurilingüe, pues su carta magna expone un conjunto de artículos que hacen alusión a la diversidad étnica, cultural y lingüística presentes en el territorio nacional, además de presentar una serie de artículos para garantizar su supervivencia, proponiendo la educación étnica y bilingüe. (Pulido, 2012, p. 233)

Por ello, el derecho a la educación intercultural bilingüe es un derecho fundamental reconocido en su máximo instrumento normativo, y constituye una garantía para que los respectivos grupos étnicos puedan obtener oportunidades de recibir una educación de calidad desde las aristas culturales y lingüísticas. El artículo 70 de su Constitución expresa que "el Estado tiene el deber de promover y fomentar el acceso a la cultura de todos los colombianos en igualdad de oportunidades, por medio de la educación permanente y la enseñanza científica, técnica, artística y profesional en todas las etapas del proceso de creación de la identidad nacional".

Asimismo, la jurisprudencia colombiana ha señalado que "la Carta elevó al rango de principios fundantes del Estado, la pluralidad y la participación; estableciendo la obligación estatal de reconocer y proteger la identidad cultural al merecer todas igual respeto por su dignidad"34; y que "el derecho fundamental a la etnoeducación ha sido desarrollado como una forma de materializar la autonomía, identidad étnica y cultural de las comunidades, pues una manera adecuada de preservar los usos y costumbres de una comunidad indígena, es la de garantizar que la educación que se les ofrece a las nuevas generaciones de esta comunidad se desarrolle conforme a sus tradiciones, creencias, lenguas y los conocimientos fundados en la historia de sus antepasados ${ }^{35 \prime \prime}$.

32 Tribunal Constitucional Plurinacional. Declaración Constitucional Plurinacional 0009/2017, Expediente N095202014-20-CEA, fundamento II-A. Recuperado de : https://buscador.tcpbolivia.bo/(S(tgugwcfnky1vn1u2f4vr1qea))/ WfrJurisprudencia.aspx

33 Constitución Política de Colombia. 1991. Artículo 7. El Estado reconoce y protege la diversidad étnica y cultural de la Nación colombiana. Artículo 8. Es obligación del Estado y de las personas proteger las riquezas culturales y naturales de la Nación. Artículo 9. Las relaciones exteriores del Estado se fundamentan en la soberanía nacional, en el respeto a la autodeterminación de los pueblos y en el reconocimiento de los principios del derecho internacional aceptados por Colombia. De igual manera, la política exterior de Colombia se orientará hacia la integración latinoamericana y del Caribe.

34 Corte Constitucional Colombiana. Sentencia T-871/13 fundamento 2.3.2.

35 Corte Constitucional Colombiana. Sentencia T-871/13 fundamento 2.3.4. 
En cuanto a las políticas educativas de la educación intercultural bilingüe, a lo largo de la década 1994-2004, Colombia ha realizado diferentes iniciativas con el propósito de medir el impacto de los cambios y tendencias generados por su Constitución de y en un contexto de convivencia de grupos étnicos culturalmente diferenciados ${ }^{36 \prime}$.

\subsection{Ecuador}

El Estado Constitucional de Ecuador en su Carta Magna vigente ${ }^{37}$ reconoce la diversidad cultural y lingüística situada en su territorio, puesto que en su artículo $2^{\circ}$ señala que "(...) el castellano es el idioma oficial del Ecuador; el castellano, el kichwa y el shuar son idiomas oficiales de relación intercultural. Los demás idiomas ancestrales son de uso oficial para los pueblos indígenas en las zonas donde habitan y en los términos que fija la ley. El Estado respetará y estimulará su conservación y uso (...)", como podemos observar, algunas lenguas originarias son consideradas como oficiales a raíz del fenómeno de la interculturalidad.

Con respecto a la educación intercultural bilingüe, en su artículo 29 señala que "el Estado garantizará la libertad de enseñanza, la libertad de cátedra en la educación superior, y el derecho de las personas de aprender en su propia lengua y ámbito cultural"; y en su artículo 343 determina que "(...) el sistema nacional de educación integrará una visión intercultural acorde con la diversidad geográfica, cultural y lingüística del país, y el respeto a los derechos de las comunidades, pueblos y nacionalidades"; en ese sentido, el Estado ecuatoriano tiene normativa y políticas públicas para garantizar la educación intercultural bilingüe partiendo desde un marco constitucional.

Según el Ministerio de Educación de Ecuador la población autoidentificada como indígena que asistió a clases entre la educación general básica y el bachillerato en el 2006, fue de 95.471 estudiantes, y al 2014, fue de 148.956 estudiantes, por ello se ha aspirado que el crecimiento se haya sostenido, para que de esa manera, todos los autoidentificados como indígenas, tengan una educación intercultural bilingüe de calidad. En el 2006, la tasa neta de asistencia a educación general básica identificada como indígena fue de $88.87 \%$ (234.065 estudiantes), y al 2014, fue de 95,73\% (264.098 estudiantes). La principal meta de la EIB en Ecuador, es que todos los estudiantes indígenas terminen el bachillerato. ${ }^{38}$

\footnotetext{
36 Vídeo "Educación Intercultural en Colombia" - Universidad Pedagógica Nacional.Recuperado de: https://www.youtube.com/watch?v=TL7r7sKuknM

37 Constitución de la República de Ecuador, entró en vigencia el 20 de octubre de 2008

38 Vídeo "Educación Intercultural Bilingüe"- Ministerio de Educación Ecuatoriano. Disponible en: https://www.youtube.com/watch?v=Q0AAdu24XAU
} 
Al respecto, Cornejo (2008) señala que "la necesidad de que la institución educativa se relacione con la comunidad y de que sea parte de ella como un organismo más del sistema interno, constituye una de las necesidades más urgentes" (p.72) en el marco ecuatoriano y que por ello se promulga la Ley Orgánica de Educación Intercultural (LOEI) ${ }^{39}$ que en su artículo $1^{\circ}$ determina expresamente que se debe garantizar el derecho a la educación, mediante la determinación de los principios y fines generales que orientan su educación ecuatoriana en el marco del Buen Vivir, la interculturalidad y la plurinacionalidad; así como las relaciones entre sus actores. Asimismo, en su artículo 77 señala que el Sistema de Educación Intercultural Bilingüe comprende el conjunto articulado de todas las políticas, normas e integrantes de la comunidad educativa desde el nivel comunitario, circuitos educativos, distrital y zonal, que tengan relación directa con los procesos de aprendizajes en idiomas ancestrales y oficiales, como principal ente para salvaguardar el derecho a la educación intercultural bilingüe de los niños, niñas y adolescentes miembros de un pueblo originario.

\subsection{Canadá}

El Estado de Canadá es un gobierno monárquico parlamentario federal, conformado por 10 provincias, y cada una de ellas con competencias distintas. Su población está conformada por ascendencia británica y francesa, quienes constituyen los grupos étnicos más grandes en su territorio, con el $40 \%$ de las poblaciones británicas y el $27 \%$ de las francesas. Los canadienses franceses e ingleses están distribuidos de manera desigual en todo el territorio ${ }^{40}$, por ello, Canadá es considerado como un Estado Bilingüe, que en su Constitución vigente ${ }^{41}$, artículo $133^{42}$, reconoce su bilingüismo; y el fomento de la educación intercultural bilingüe.

El derecho a la instrucción primaria o secundaria y el uso del idioma, son derechos fundamentales de orden constitucional, reconocidos en su Carta Magna vigente. Según Morin (2017) "los derechos lingüísticos en Canadá tienen como objetivo respetar y promover los derechos humanos comunidades minoritarias para que florezcan en todo el país. Dado que su

\footnotetext{
Ley Orgánica de Educación Intercultural, publicada el 31 de marzo de 2011.

Enseignement Bilingüe au Canadá. Recuperado de: http://www.unavarra.es/tel21/fr/canada.htm

Constitución Canadiense. Leyes Constitucionales Canadienses de 1867 a 1982.

12 Constitución Canadiense. Artículo 133.- En las Cámaras del Parlamento de Canadá y las Casas de la Legislatura de uso opcional y obligatoria de Quebec, el uso de la lengua francesa o del idioma inglés, en los debates, serán facultativo la lengua francesa e inglesa; pero en la redacción de los respectivos archivos, minutas y diarios de estos salas, el uso de estos dos idiomas será obligatorio; y en cualquier alegato o exhibición de procedimientos antes o a través de los tribunales de Canadá que se establecerán bajo la autoridad de esta Ley, y ante cualquier tribunal o que emane de los tribunales de Quebec, el uso de uno u otro de estos idiomas también puede ser utilizado. Si existen padres que hablan francés y viven en una provincia de habla inglesa, pueden exigir que sus hijos vayan a los colegios de habla inglesa.
} 
interpretación debe ser coherente con su propósito, debe ser coherente con el mantenimiento de las comunidades de idioma oficial en Canadá" (p.4), contribuyendo así con el fomento de la educación bilingüe.

Asimismo, existen otros instrumentos jurídicos en marco interno que protegen el bilingüismo enfocado en la educación. La Carta Canadiense de los Derechos y Libertades ${ }^{43}$, que en su artículo $16^{44}$ reconoce al inglés y francés como lenguas oficiales del Estado Canadiense, y el artículo $23^{45}$ que señala el derecho a la educación del ciudadano canadiense según uso de idioma, este sea inglés o francés, por ejemplo, "si existen padres que hablan francés y viven en una provincia de habla inglesa, pueden exigir que sus hijos vayan a los colegios de habla inglesa". Además, Canadá ha implementado una serie de políticas públicas que regulan los programas de financiación de componentes públicos relacionados con la educación, de esa manera, el Gobierno federal transfiere los fondos para estas actividades a sus diversas provincias y territorios ${ }^{46}$.

\section{AVANCES ESTATALES}

\subsection{Poder Ejecutivo}

\subsubsection{Ministerio de Educación (MINEDU)}

Según el Ministerio de Educación (MINEDU), “la Educación Intercultural Bilingüe tiene como principal objetivo motivar y apoyar a los estudiantes a ser los constructores de sus propios aprendizajes ${ }^{47 \prime \prime}$. Para ello, han distribuido material educativo en 27 lenguas para 625 mil escolares de 17 mil escuelas interculturales bilingües. Los textos están en quechua y en sus variantes

43 Carta Canadiense de los Derechos y Libertades, adoptada en 1982

44 Carta Canadiense de los Derechos y Libertades. Artículo 16.- (1) El francés y el inglés son las lenguas oficiales de Canadá; tienen condición de igualdad y derechos y privilegios iguales con respecto a su uso en las instituciones del Parlamento y del gobierno de Canadá.

45 Carta Canadiense de los Derechos y Libertades. Artículo 23.- (1) Los ciudadanos canadienses: a. cuya primera lengua aprendida y aun comprendida es la de la minoría francófona o anglófona de la provincia donde residen, b. que han recibido su instrucción primaria en francés o en inglés en Canadá y que residen en una provincia cuya lengua en la cual han recibido dicha instrucción es la de la minoría francófona o anglófona de la provincia tienen, en uno u otro caso, el derecho de educar a sus hijos, a nivel primario y secundario, en esta lengua. (2) Los ciudadanos canadienses de los cuales un hijo ha recibido o recibe su educación, a nivel primario o secundario, en francés o en inglés en Canadá tiene derecho a instruir a todos sus hijos, en los niveles primario y secundario, en esta lengua de instrucción. (3) el derecho reconocido a los ciudadanos canadienses por los párrafos (1) y (2) de instruir a sus hijos, a niveles primario y secundario, en la lengua de la minoría francófona o anglófona de una provincia: a.se aplica en cualquier parte de la provincia donde el número de hijos de ciudadanos que disfrutan de este derecho es suficiente para justificar la prestación, con cargo al erario público, de la instrucción en la lengua de la minoría; b. comprende, cuando el número de estos niños lo justifica, el derecho de instruirles en centros de enseñanza de la minoría lingüística financiados por el erario público.

46 Centro de Estudios Constitucionales. I Seminario de Derechos Lingüísticos y Justicia Constitucional. Ponencia de: Álvaro Córdova Flores, Asesor del Tribunal Constitucional Peruano, 21 de junio de 2018.

47 Ministerio de Educación. En el Perú hay 47 lenguas originarias que son habladas por cuatro millones de personas. Noticia publicada el 26 de mayo de 2017. Recuperado de: http:/ / www.minedu.gob.pe/n/noticia.php?id=42914 
(collao, chanka, central, kichwa amazónico, incawasi Cañaris), aimara, awajún, ashaninka, shipibo-konibo, shawi, matsigenka, nomatsigenga, kakinte, achuar, wampis, urarina, cashinahua, harakbut, matsés, jaqaru, yine, ese eja, kakataibo, kandozi, chapra, yanesha y murui-muinani ${ }^{48}$.

Teniendo en cuenta que la Ley $\mathrm{N}^{\circ}$ 27818, Ley Educación Bilingüe Intercultural, establece como objetivo la creación de una política pública en la materia; mediante Resolución Suprema N 001-2007-ED, se aprobó el "Proyecto Educativo Nacional al 2021: La Educación que queremos para el Perú" y mediante Resolución Ministerial N 629-2016-MINEDU, el "Plan Nacional de Educación Intercultural Bilingüe hacia el $2021^{49 \prime}$, las cuales se orientan a formar niños, niñas, adolescentes, jóvenes, personas adultas y personas adultas mayores de pueblos originarios a la educación partiendo de una sociedad pluricultural y multilingüe.

El citado Plan Nacional tiene cuatro objetivos principales: 1) acceso, permanencia y culminación oportuna en la educación intercultural bilingüe (EIB), 2) currículo pertinente y propuesta pedagógica EIB, 3) formación inicial y en servicio de docentes EIB y 4) gestión descentralizada y participación social en EIB. A continuación, se detallará cada uno de ellos:

\begin{tabular}{|c|c|c|c|}
\hline $\begin{array}{c}\text { 1) Acceso, permanencia y } \\
\text { culminación oportuna en } \\
\text { la Educación Intercultural } \\
\text { Bilingüe (EIB }\end{array}$ & $\begin{array}{l}\text { 2) Currículo pertinente y } \\
\text { propuesta pedagógica EIB }\end{array}$ & $\begin{array}{l}\text { 3) Formación inicial y en } \\
\text { servicio de docentes EIB }\end{array}$ & $\begin{array}{l}\text { 4) Gestión descentralizada } \\
\text { y participación social en } \\
\text { EIB }\end{array}$ \\
\hline $\begin{array}{c}\text { Objetivo: } \\
\text { Lograr el acceso a los } \\
\text { niños, niñas, adolescentes, } \\
\text { jóvenes, personas adultas y } \\
\text { personas adultas mayores } \\
\text { de los pueblos originarios } \\
\text { un servicio educativo que } \\
\text { garantice su derecho a la } \\
\text { educación intercultural } \\
\text { bilingüe y que culminen } \\
\text { de manera "oportuna" } \\
\text { todas las etapas de } \\
\text { formación educativa. }\end{array}$ & $\begin{array}{c}\text { Objetivo: } \\
\text { Garantizar el desarrollo de } \\
\text { enseñanzas y aprendizaje, } \\
\text { para que garantice el } \\
\text { derecho a la educación } \\
\text { intercultural bilingüe a los } \\
\text { niños, niñas, adolescentes, } \\
\text { jóvenes, personas adultas y } \\
\text { personas adultas mayores } \\
\text { pertenecientes de los } \\
\text { pueblos originarios. } \\
\text { Asimismo, el diseño del } \\
\text { currículo para los } \\
\text { integrantes de pueblos } \\
\text { originarios que busca } \\
\text { fortalecer y revitalizar la } \\
\text { lengua originaria, } \\
\text { orientaciones culturales y } \\
\text { fundamentar la } \\
\text { interculturalidad. }\end{array}$ & $\begin{array}{l}\text { Objetivo: } \\
\text { Implementar formación } \\
\text { docente bilingüe para que } \\
\text { pueda brindar una calidad } \\
\text { educativa a los miembros } \\
\text { de los pueblos originarios. }\end{array}$ & $\begin{array}{c}\text { Objetivo: } \\
\text { Promover la participación } \\
\text { activa y efectiva de los } \\
\text { miembros de los pueblos } \\
\text { originarios; padres, madres, } \\
\text { hijos, etc. de esta manera, se } \\
\text { realiza una gestión } \\
\text { intercultural en las escuelas } \\
\text { donde predominan las } \\
\text { lenguas originarias como } \\
\text { lengua materna y contribuir } \\
\text { con la implementación de la } \\
\text { política nacional EIB. }\end{array}$ \\
\hline
\end{tabular}

48 Ministerio de Educación. MINEDU exhibe alfabetos oficiales y materiales educativos en lenguas originarias, publicada el 22 de mayo de 2018. Recuperado de: http://www.minedu.gob.pe/n/noticia.php?id=46749

49 Aprobado por Resolución Ministerial N629-2016-MINEDU. 


\begin{tabular}{|c|c|c|c|}
\hline $\begin{array}{c}\text { Avances: } \\
\text { Mediante Resolución } \\
\text { Ministerial N²46-2012- } \\
\text { ED, se creó la Comisión } \\
\text { Nacional de Educación } \\
\text { Intercultural y Bilingüe } \\
\text { (CONEIB) como espacio de } \\
\text { participación y } \\
\text { concertación entre el } \\
\text { Ministerio de Educación y } \\
\text { las organizaciones de los } \\
\text { 20 pueblos indígenas } \\
\text { andinos y amazónicos y las } \\
\text { organizaciones } \\
\text { afroperuanas, con el } \\
\text { objetivo de contribuir en la } \\
\text { implementación de las } \\
\text { políticas de Educación } \\
\text { Intercultural y Bilingüe, } \\
\text { impartiendo el acceso de la } \\
\text { educación EIB a los } \\
\text { miembros de los pueblos } \\
\text { indígenas, erradicando } \\
\text { cualquier tipo de brecha } \\
\text { que no permita el acceso, } \\
\text { permanencia y } \\
\text { culminación. }\end{array}$ & $\begin{array}{c}\text { Avances: } \\
\text { Se están implementando } \\
\text { currículos con propuestas } \\
\text { pedagógicas de EIB, y } \\
\text { aseguran dotación, } \\
\text { distribución oportuna y uso } \\
\text { de recursos educativos. }\end{array}$ & $\begin{array}{c}\text { Avances: } \\
\text { Mediante Resolución } \\
\text { Directoral N }{ }^{\circ} 037-2014- \\
\text { MINEDU/VMGP- } \\
\text { DIGESUTP, se rectificó el } \\
\text { diseño curricular de } \\
\text { algunas carreras } \\
\text { profesionales y se asumió el } \\
\text { compromiso por la } \\
\text { formación de docentes EIB. }\end{array}$ & $\begin{array}{c}\text { Avances: } \\
\text { Es más recurrente la } \\
\text { participación de los } \\
\text { familiares y miembros de } \\
\text { un determinado pueblo } \\
\text { indígena, pues, son } \\
\text { prescindibles para que el } \\
\text { niño pueda continuar con } \\
\text { las prácticas de sus } \\
\text { respectivos usos y } \\
\text { costumbres, además del uso } \\
\text { constante de la lengua } \\
\text { materna, de esa manera, la } \\
\text { participación colectiva en la } \\
\text { educación intercultural } \\
\text { bilingüe no solo se vuelve } \\
\text { social sino también } \\
\text { constructivo y didáctico. }\end{array}$ \\
\hline
\end{tabular}

\subsubsection{Ministerio de Cultura}

Elaboración propia.

El Ministerio de Cultura ha recopilado información relevante acerca de las lenguas originarias, mapas etnolingüísticas y búsqueda de localidades. Todos estos registros son sumamente importantes y van de la mano con el desarrollo del derecho a la educación intercultural bilingüe porque de esa manera se protege la identidad cultural y lingüística de las 47 lenguas originarias, fomentándose así la educación desde la personificación cultural y lingüística.

\section{Asimismo, es preciso señalar que el "Plan Nacional de Educación} Intercultural Bilingüe" es de gran interés para el Ministerio de Cultura, debido a que la educación con enfoque intercultural es una herramienta para reforzar, proteger y velar por los derechos colectivos de los pueblos indígenas, consolidando de esta manera la propia identidad cultural, lengua y los conocimientos colectivos y ancestrales de los pueblos ${ }^{53}$.

50 Ministerio de Educación. Objetivo 2. Recuperado de:http://www.minedu.gob.pe/campanias/pdf/2_objetivo.pdf

51 Plan Nacional de Educación Intercultural Bilingüe. Objetivo 3. Recuperado de: $\underline{\text { http: // repositorio.minedu.gob.pe/ }}$ bitstream/handle/123456789/5105/Plan\%20Nacional\%20de\%20Educaci\%C3\%B3n\%20Intercultural\%20Biling $\%$ C3\%BCe \%20al\%202021.pdf?sequence $=1 \&$ isAllowed $=y$

52 Plan Nacional de Educación Intercultural Bilingüe. Objetivo 4. Recuperado de: $\underline{\mathrm{http}}: / /$ repositorio.minedu.gob.pe/ bitstream/handle/123456789/5105/Plan\%20Nacional\%20de\%20Educaci\%C3\%B3n\%20Intercultural\%20Biling\%C3\%BCe\%20al\%202021.pdf? sequence $=1 \&$ is Allowed $=y$

53 Ministerio de Cultura. Noticia: Se aprueba el Plan Nacional de Educación Intercultural Bilingüe. Recuperado de: http://www.cultura.gob.pe/comunicacion/noticia/se-aprueba-el-plan-nacional-de-educacion-intercultural-bilingue 
También, el Decreto Supremo Nº05-2017-MC, que emana de dicho Ministerio y aprueba la Política Nacional de Lenguas Originarias, Tradición Oral e Interculturalidad ${ }^{54}$, tiene como objetivo garantizar los derechos lingüísticos de los hablantes de lenguas indígenas u originarias en el ámbito nacional, política pública que sin duda garantiza la vigencia efectiva de los derechos lingüísticos de los miembros de los pueblos originarios en las entidades estatales.

\subsubsection{Ministerio de la Mujer y Poblaciones Vulnerables}

El Ministerio de la Mujer y Poblaciones Vulnerables (MIMP) asume el compromiso estatal de diseñar, promover, coordinar, supervisar y evaluar las políticas, planes, programas y proyectos en favor de las mujeres y poblaciones vulnerables, entre las cuales se identifican las niñas, niños y adolescentes.

Dada la gran preocupación por la niñez peruana, el MIMP aprobó mediante Decreto Supremo N001-2012-MIMP, el Plan Nacional de Acción por la Infancia y la Adolescencia - PNAIA 2012-2021, que está divido en 6 metas emblemáticas y 4 objetivos estratégicos, con la visión que los niños, niñas y adolescentes en el Perú tengan igualdad de oportunidades en el ejercicio de sus derechos fundamentales.

Respecto a dicho Plan, debemos señalar que en 3 de sus 6 metas emblemáticas se refleja el compromiso del Estado Peruano por respetar, proteger y garantizar el derecho a la educación intercultural bilingüe a la niñez indígena, y ello se refleja en la segunda meta emblemática intitulada: "El 100\% de las niñas y niños peruanos de 3 a 5 años de edad acceden a educación inicial de calidad".

En ese orden de ideas, la tercera meta emblemática intitulada: "El $70 \%$ de las niñas y niños peruanos de segundo grado de primaria alcanza un nivel suficiente de comprensión lectora y razonamiento matemático", es significativa para el progreso educacional de la niñez, especialmente en la niñez indígena, quienes deben recibir una educación suficiente en el tratamiento de razonamiento verbal y matemático desde su cosmovisión cultural y lingüística.

Finalmente, la quinta meta emblemática intitulada: "Las y los adolescentes acceden y concluyen en la edad normativa, una educación secundaria de calidad", promueve el acceso a la educación secundaria en los adolescentes, y es que estos

54 Publicado en el Diario Oficial el Peruano el 10 de agosto de 2017. 
son los futuros jóvenes de una nueva generación y es importante brindar una educación de calidad para que desarrollen todas sus actividades, en especial de formación intelectual de nuestros pueblos originarios. A continuación una breve descripción de las seis metas emblemáticas del citado Plan Nacional:

\begin{tabular}{|c|c|c|c|c|c|}
\hline $\begin{array}{l}\text { 1)Desnutrición crónica } \\
\text { de la primera infancia } \\
\text { reducida al } 5 \%\end{array}$ & $\begin{array}{c}\text { 2) El } 100 \% \text { de las } \\
\text { niñas y niños } \\
\text { peruanos de } 3 \text { a } 5 \\
\text { años de edad accede } \\
\text { a educación inicial } \\
\text { de calidad. }\end{array}$ & $\begin{array}{l}\text { 3) El } 70 \% \text { de las } \\
\text { niñas y niños } \\
\text { peruanos de } \\
\text { segundo grado de } \\
\text { primaria alcanza } \\
\text { un nivel suficiente } \\
\text { de comprensión } \\
\text { lectora y } \\
\text { razonamiento } \\
\text { matemático. }\end{array}$ & $\begin{array}{l}\text { 4) La tasa de } \\
\text { maternidad } \\
\text { adolescente se } \\
\text { reduce en un } \\
20 \% .\end{array}$ & $\begin{array}{l}\text { 5) Las y los } \\
\text { adolescentes } \\
\text { acceden y } \\
\text { concluyen en la } \\
\text { edad normativa, } \\
\text { una educación } \\
\text { secundaria de } \\
\text { calidad. }\end{array}$ & $\begin{array}{l}\text { 6) ¡En el Perú no } \\
\text { se maltrata a su } \\
\text { infancia! } \\
\text { Disminuye } \\
\text { violencia familiar } \\
\text { contra niñas, } \\
\text { niños y } \\
\text { adolescentes }\end{array}$ \\
\hline Objetivo: & Objetivo: & Objetivo: & Objetivo: & Objetivo: & Objetivo: \\
\hline $\begin{array}{l}\text { La presente meta } \\
\text { emblemática postula } \\
\text { que para el } 2021 \text { el Perú } \\
\text { habrá reducido al } 5 \% \text { la } \\
\text { desnutrición infantil } \\
\text { crónica; es decir, el } 95 \% \\
\text { de las niñas y niños } \\
\text { entre } 0 \text { y } 5 \text { años de edad } \\
\text { gozará de nutrición } \\
\text { adecuada. }\end{array}$ & $\begin{array}{c}\text { Proporcionar } \\
\text { educación inicial a } \\
\text { todas las niñas y } \\
\text { niños peruanos de } 3 \text { a } \\
5 \text { años de edad Su } \\
\text { consecución será } \\
\text { clave para poner fin } \\
\text { al circuito de } \\
\text { regeneración de la } \\
\text { pobreza en el país, } \\
\text { pues no existe mejor } \\
\text { garantía de avance } \\
\text { social y económico } \\
\text { que una comunidad } \\
\text { tempranamente } \\
\text { educada. }\end{array}$ & $\begin{array}{l}\text { Proporcionar una } \\
\text { educación } \\
\text { adecuada a las } \\
\text { niñas y niños de } \\
\text { segundo grado de } \\
\text { primaria en lo que } \\
\text { concierne a } \\
\text { comprensión } \\
\text { lectora y } \\
\text { razonamiento } \\
\text { matemático, para } \\
\text { que de esa manera } \\
\text { las niñas y niños } \\
\text { puedan } \\
\text { desarrollarse } \\
\text { intelectualmente } \\
\text { de la manera } \\
\text { correcta y reforzar } \\
\text { conocimientos } \\
\text { vitales para su } \\
\text { progreso } \\
\text { intelectual. }\end{array}$ & $\begin{array}{c}\text { Reducir la } \\
\text { maternidad } \\
\text { prematura a la } \\
\text { mitad de las } \\
\text { actuales tasas, } \\
\text { para evitar la } \\
\text { recurrencia de un } \\
\text { problema } \\
\text { bastante común, } \\
\text { pero con altísimo } \\
\text { costo social. }^{58}\end{array}$ & $\begin{array}{c}\text { Brindar a las y los } \\
\text { adolescentes que } \\
\text { cursan secundaria, } \\
\text { una educación de } \\
\text { calidad que } \\
\text { consolide y amplíe } \\
\text { los aprendizajes } \\
\text { adquiridos en la } \\
\text { primaria, } \\
\text { particularmente } \\
\text { en aquellas } \\
\text { competencias que } \\
\text { les abran } \\
\text { oportunidades al } \\
\text { conocimiento, al } \\
\text { emprendimiento } \\
\text { productivo y a la } \\
\text { vida democrática. }\end{array}$ & $\begin{array}{c}\text { Focalizar acciones } \\
\text { en las zonas con } \\
\text { mayor incidencia } \\
\text { de maltrato a la } \\
\text { niñez, así como } \\
\text { aplicar en el año } \\
2012 \text { la primera } \\
\text { Encuesta Nacional } \\
\text { Especializada } \\
\text { sobre Violencia } \\
\text { contra Niñas, } \\
\text { Niños y } \\
\text { Adolescentes, a fin } \\
\text { de establecer una } \\
\text { línea de base, } \\
\text { cuantificar metas } \\
\text { y monitorear en lo } \\
\text { pertinente las } \\
\text { acciones del } \\
\text { PNAIA } 2021{ }^{60}\end{array}$ \\
\hline
\end{tabular}

\subsection{Poder Legislativo}

Nuestros parlamentarios en distintas oportunidades han ratificado públicamente el compromiso estatal con los pueblos originarios del Perú. ${ }^{61}$ Asimismo, han presentado proyectos de Ley que tienen como objetivo

55 Plan Nacional de Acción por la Infancia y Adolescencia 2012-2021. PNAIA 2021. Recuperado de: https://www. mimp.gob.pe/webs/mimp/pnaia/pdf/Documento_PNAIA.pdf

56 Plan Nacional de Acción por la Infancia y Adolescencia 2012-2021. PNAIA 2021. Recuperado de: https://www. mimp.gob.pe/webs/mimp/pnaia/pdf/Documento PNAIA.pdf

57 Íbidem

58 Íbidem.

69 Íbidem.

60 Íbidem

${ }^{61}$ Vídeo "Congresista Claudia Coari saluda a los Pueblos Indígenas en su día"- Congreso de la República del Perú. Recuperado de: https: / / www.youtube.com/watch?v=-fwGaUTv4-U 
principal la defensa de las lenguas originarias y la impartición de la educación hacia los miembros de los pueblos indígenas en el Perú, de los cuales resaltamos los siguientes:

\begin{tabular}{|c|c|c|c|c|}
\hline $\begin{array}{l}\text { Proyecto } \\
\text { de Ley }\end{array}$ & $\begin{array}{c}\text { Fecha de } \\
\text { presentación }\end{array}$ & Propuesta & Relación con EIB & Estado actual \\
\hline 02448/2017-CR & $21 / 02 / 2018$ & $\begin{array}{l}\text { Propone modificar el } \\
\text { artículo } 48 \text { de la } \\
\text { Constitución Política del } \\
\text { Perú insertando la } \\
\text { denominación "lenguas } \\
\text { indígenas u originarias" } \\
\text { por la de "lenguas } \\
\text { aborígenes", acorde con la } \\
\text { legislación nacional e } \\
\text { internacional que } \\
\text { garantiza el uso de la } \\
\text { lengua indígena u } \\
\text { originaria como parte de } \\
\text { la identidad de los } \\
\text { pueblos. }\end{array}$ & $\begin{array}{c}\text { Este proyecto de ley } \\
\text { pretende modificar el } \\
\text { artículo } 48 \text { de la Carta } \\
\text { Magna vigente, que regula } \\
\text { el reconocimiento oficial del } \\
\text { uso de las lenguas } \\
\text { originarias. } \\
\text { En cuanto a la relación con } \\
\text { la EIB, este proyecto de ley, } \\
\text { trataría de adecuar el uso } \\
\text { correcto del término de } \\
\text { "lenguas originarias" por } \\
\text { "lenguas aborígenes" como } \\
\text { lo señalan instrumentos } \\
\text { jurídicos internacionales, y, } \\
\text { de esa manera existiría un } \\
\text { cambio en términos en las } \\
\text { leyes especiales y políticas } \\
\text { públicas que regulan el } \\
\text { derecho a la educación } \\
\text { intercultural bilingüe. }\end{array}$ & En Comisión ${ }^{62}$ \\
\hline 02423/2017-CR & $15 / 02 / 2018$ & $\begin{array}{l}\text { Propone modificar el } \\
\text { artículo } 21 \text { e incorporase } \\
\text { al Capítulo V } \\
\text { Normalización } \\
\text { lingüística de la Ley } \\
\text { 29735, Ley que regula el } \\
\text { uso, preservación, } \\
\text { desarrollo, recuperación, } \\
\text { fomento y difusión de } \\
\text { las lenguas originarias } \\
\text { del Perú. }\end{array}$ & $\begin{array}{c}\text { Este proyecto de ley } \\
\text { pretende modificar el } \\
\text { artículo } 21 \text { de la Ley } \\
29735, \text { que expresa lo } \\
\text { siguiente en su inciso } 1 \\
\text { “El Ministerio de } \\
\text { Educación, a través de la } \\
\text { Dirección de Educación } \\
\text { Intercultural y Bilingüe y } \\
\text { la Dirección de } \\
\text { Educación Rural, } \\
\text { proporciona asistencia } \\
\text { técnica, evalúa y } \\
\text { oficializa las reglas de } \\
\text { escritura uniformes de } \\
\text { las lenguas originarias } \\
\text { del país”; y en su inciso } 2 \\
\text { “Las entidades públicas } \\
\text { emplean versiones } \\
\text { uniformizadas de las } \\
\text { lenguas originarias en } \\
\text { todos los documentos } \\
\text { oficiales que formulan o } \\
\text { publican”. }\end{array}$ & En comisión ${ }^{63}$ \\
\hline
\end{tabular}

${ }_{62}$ Congreso de la República del Perú. Recuperado de: http://www.congreso.gob.pe/participacion/foros/proyectosdeley/ 63 Íbidem. 


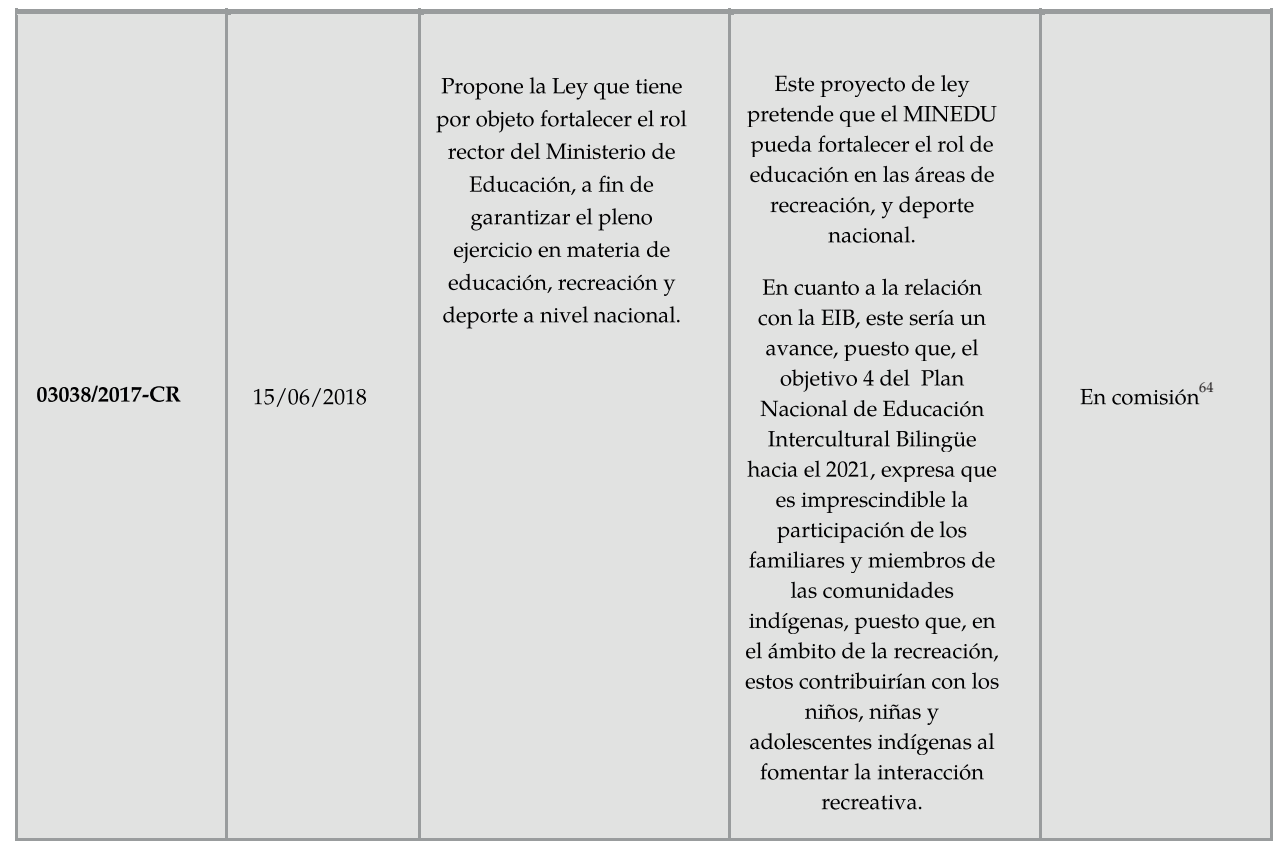

Elaboración propia.

\subsection{Poder Judicial}

En el Poder Judicial también se registran avances en el reconocimiento del uso de las lenguas originarias. A través de la creación del Registro de Traductores e Intérpretes, en el año 2015 se emitieron dos sentencias en lenguas originarias: quechua y aimara, y en el 2017 una sentencia en shipibo konibo $^{65}$. Asimismo, con la implementación de "Protocolos para una justicia intercultural" entre procesos judiciales de comuneros y ronderos en justicia ordinaria, se busca garantizar el ejercicio de los derechos constitucionales en zonas donde rigen cosmovisiones distintas.

Si bien no se registra un reconocimiento jurisprudencial del derecho a la educación intercultural, se ha podido identificar una sustanciosa jurisprudencia que vela por el principio rector del interés superior del niño ${ }^{66}$ y el derecho a la igualdad antes la Ley ${ }^{67}$, los cuales representan un valioso insumo para futuros pronunciamientos judiciales en la temática.

64 Íbidem.

65 Centro de Estudios Constitucionales. I Seminario de Derechos Lingüísticos y Justicia Constitucional. Ponencia de: Duberlí Rodríguez Tineo, ex Presidente de la Corte Suprema de Justicia de la República del Perú, 20 de junio de 2018.

${ }_{66}$ Poder Judicial del Perú. Jurisprudencia sistematizada sobre el principio del interés superior del niño. Recuperado de: https://www.pj.gob.pe/wps/wcm/connect/cij-juris/s cij jurisprudencia nuevo/as jurisprudencia sistema-

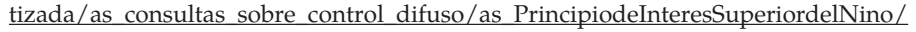

67 Poder Judicial del Perú. Jurisprudencia sistematizada sobre derecho a la igualdad antes la ley. Recuperado de: https://www.pj.gob.pe/wps/wcm/connect/cij-juris/s cij_jurisprudencia nuevo/as jurisprudencia sistematizada/as_consultas_sobre_control_difuso/as_Derechoalaigualdad/ 


\section{DESAFÍOS}

En coincidencia con el Informe Defensorial 016-2013-DP, consideramos que constituye una tarea pendiente del Estado peruano el promover la formación delos docentes de EIB del nivel secundario y además la capacitación de los maestros por parte del Ministerio de Educación. Sin duda, dicho sector debería realizar un seguimiento continuo a los profesores contratados, ya que "(..) actualmente hay muchos maestros quechuas, aimaras, asháninkas maestros bilingües que no serían titulados ${ }^{68 "}$.

Elcitadocontextoresulta preocupantetoda vezqueseestaría vulnerando la Ley de Reforma Magisterial, que exige la titulación profesional de los docentes y manejar de forma fluida la lengua materna de los estudiantes ${ }^{69}$.

Particularmente, se detecta que el artículo $56^{70}$ de la Ley de Reforma Magisterial, señala que existe una asignación temporal para los profesores quienes son docentes en aquellas zonas recónditas y están calificados como docentes bilingües, empero, como expresa el citado Informe Defensorial “(...) la supervisión ha permitido observar que en nueve (9) Unidades de Gestión Educativa (UGEL) se contrató 808 docentes sin formación ni capacitación de EIB. De igual modo, al no haberse establecido la Directiva de contratación de docente los criterios objetivos para evaluar los idiomas originarios de los postulantes" ${ }^{71}$.

Como podemos observar, la educación intercultural bilingüe de calidad es uno de los desafíos más grandes que enfrenta el Estado Peruano en todas las etapas, formas y modalidades del sistema educativo, desde una perspectiva crítica de tratamiento de la diversidad étnica, cultural y lingüística del país. ${ }^{72}$

Aunado a ello, consideramos importante resaltar lo expresado por Ruth Zenaida Buendía Mestoquiari, Secretaria General de la Asociación

${ }_{68}$ Según lo expresó Elena Burga Cabrera, Ex directora de Educación Básica Alternativa, Intercultural Bilingüe y de Servicios Educativos del ámbito rural en MINEDU. Entrevista para Perú 21. Recuperado de: https://peru21.pe/ lima/millon-ninos-peru-hablan-lenguas-originarias-77970

69 Ley N ${ }^{\circ} 29944$. Ley de Reforma Magisterial. Artículo 4.- El profesor es un profesional de la educación, con título de profesor o licenciado en educación, con calificaciones y competencias debidamente certificadas que, en su calidad de agente fundamental del proceso educativo, presta un servicio público esencial dirigido a concretar el derecho de los estudiantes y de la comunidad a una enseñanza de calidad, equidad y pertinencia. Artículo 55.- Manejar fluidamente la lengua materna de los educandos y conocer la cultura local para postular a las plazas vacantes de instituciones educativas pertenecientes a educación intercultural bilingüe.

$70 \quad$ Ley N² 29944. Ley de Reforma Magisterial. Artículo 18.2.- El profesor percibe una remuneración íntegra mensual de acuerdo a su escala magisterial y jornada de trabajo: b. Ubicación de la institución educativa: ámbito rural y de frontera. c. Característica de la institución educativa: unidocente, multigrado o bilingüe (...)"

71 Informe Defensorial 016-2013-DP. Publicada en el Diario Oficial el Peruano el 13 de setiembre de 2013.

72 Plan Nacional de Educación Intercultural Bilingüe al 2021. Recuperado de: http://www.grade.org.pe/forge/descargas/PLAN\%20EIB.pdf 
Interétnica de Desarrollo de la Selva Peruana (AIDESEP). En una entrevista ${ }^{73}$ realizada para el presente artículo, la señora Buendía expresó su inmensa preocupación por la educación intercultural bilingüe, especialmente haciendo énfasis en la niñez indígena. Según aduce, principalmente en la Amazonía, donde predominan 43 lenguas originarias, ha detectado un nefasto diseño curricular para la educación primaria y secundaria que no garantizarían una educación de calidad. Bajo ese contexto, la señora Buendía indica que su Asociación viene fomentando la educación intercultural bilingüe con un correcto diseño curricular, enfocando los elementos culturales y lingüísticos en determinadas comunidades; sin embargo, necesitarían apoyo económico del gobierno regional.

Ante ello, consideramos que también es importante que el Estado trabaje de manera conjunta con las organizaciones privadas, para articular el trabajo en favor de estos grupos mediante la uniformización de procedimientos y metodologías educativas.

\section{CONCLUSIONES}

1.- El derecho a la educación intercultural bilingüe es un derecho fundamental de orden constitucional innato de los pueblos indígenas, pues, enmarca la protección de la riqueza cultural y lingüística arraigada a la educación.

2.- Existen distintos instrumentos jurídicos nacionales e internacionales que protegen el derecho a la educación intercultural bilingüe para el progreso del niño indígena, desde los ejes: culturales y lingüísticos.

3.-La educación intercultural bilingüe en el Perú ha logrado desarrollo normativo, jurisprudencial y doctrinario en el ordenamiento jurídico interno acorde con lo avanzado a nivel internacional.

4.- La participación de la comunidad indígena hacia la fomentación de la educación intercultural bilingüe y la presencia de pocos docentes bilingües originarios quienes no tienen un nivel avanzado escrito $u$ oral de la lengua originaria a enseñar, representan los principales desafíos estatales en la materia.

\section{RECOMENDACIONES}

1.- Garantizar la vigencia efectiva del derecho a la educación intercultural bilingüe de la niñez indígena, implementando mayores

Entrevista realizada por Nuccia Seminario Hurtado el 28 de febrero de 2018. 
escuelas interculturales bilingües que cuente con el personal docente debidamente capacitado para fomentar la enseñanza desde las aristas: culturales y lingüísticas.

2.- Fomentar el uso de la lengua originaria en la educación para que de esa manera no se extinga la riqueza lingüística que posee nuestro territorio, por ello, se debe seguir institucionalizando la lengua como uso continuo en las comunidades indígenas.

3.- Ratificar el Protocolo Facultativo del Pacto Internacional de los Derechos Económicos, Sociales y Culturales, para que las recomendaciones emitidas por su Comité ante posibles denuncias de particulares respecto al derecho a la educación intercultural bilingüe sean puestas en práctica por el Estado Peruano.

4.- Impulsar la participación indígena a través de programas de vecindad que refuercen el uso de la lengua originaria en aquellos determinados espacios geográficos donde predomina una lengua que no es castellano, para que de esa manera, el niño que se identifica como indígena, pueda seguir siendo partícipe dentro de su desarrollo y fomento de bilingüismo originario.

\section{REFERENCIAS}

Abarca, G. (2015). Educación Intercultural Bilingüe: Educación y Diversidad. En: Apuntes Educación y Desarrollo Post 2015- N9. Recuperado de: http://www.unesco.org/new/fileadmin/MULTIMEDIA/FIELD/Santiago/ pdf/APUNTE09-ESP.pdf

Castillo, C. (2009). Estudios sobre educación intercultural en Colombia: tendencias y perspectivas. Memorias, pp. 358-375.

Comisión Interamericana de Derechos Humanos. Informe Consultivo. (2017).Hacia la garantía efectiva de los derechos de niñas, niños y adolescentes: Sistemas Nacionales de Protección. Recuperado de: http://www.oas.org/es/ cidh/informes/pdfs/NNA-GarantiaDerechos.pdf

Conejo, A. (2008). Educación Intercultural Bilingüe en el Ecuador. La propuesta educativa y su proceso. Comunicación y Sociedad. Recuperado de:https: / / www.dspace.ups.edu.ec/bitstream/123456789/8090/1/ Educaci\%C3\%B3n\%20intercultural\%20biling\%C3\%BCe\%20en \%20el\%20 Ecuador.pdf 
Corte Constitucional Colombiana. Sentencia T-871/13. Recuperado de: http://www.corteconstitucional.gov.co/relatoria/2013/T-871-13.htm

Dirección General de Educación Bilingüe (1989). Política de educación bilingüe intercultural. Lima: Ministerio de Educación.

García, V. (2008). Los derechos fundamentales en el Perú. Lima:Jurista Editores.

Godoy, L. (2015). Educación Intercultural Bilingüe en Bolivia. En: Revista ReveLa. Recuperado de: http://revistarevela.com/educacion-interculturalbilingue-en-bolivia/

Gonzáles, J. (2015). Educación, desarrollo y cohesión social. $1^{a}$ ed. Cuenca: Universidad Castilla de la Mancha.

Ministerio de Cultura (2013). 10 cosas que debes saber de las lenguas indígenas peruanas y sus hablantes. Recuperado de: http://www.cultura.gob.pe/ sites/default/files/paginternas/tablaarchivos/2013/05/10cosasquedebessabersobrelenguasindigenas.pdf

Ministerio de Cultura (2014). Etapa de Identificación de los pueblos indígenas u originarios. $1^{\mathrm{a}} \mathrm{Ed}$. Lima: Ministerio de Cultura.

Ministerio de Cultura. Tríptico de Traductores e ínterpretes de Lenguas Indígenas. Recuperado de: http://www.cultura.gob.pe/sites/ default/files/Ttriptico.pdf

Ministerio de Educación (2013). Documento Nacional de Lenguas Originarias del Perú. Lima: Biblioteca Nacional del Perú. Recuperado de: http:// www2.minedu.gob.pe/filesogecop/DNL-version\%20final\%20WEB.pdf

Ministerio de Educación de Canadá (2008). L'Éducation au Canada. Conseil des Ministers de l'Éducation. Recuperado de: https://www.cicic.ca/ docs/cmec/EducationCanada2008.fr.pdf

Morin, C. (2017). Le bilinguisme des juges à la Cour suprême : fondement de l'égalité au Canada. Recuperado de: http://odl.openum.ca/ files/sites/68/2017/05/Le-bilinguisme-des-juges-a-la-Cour-supremefondement-de-legalite-au-Canada-FINAL.pdf

Ordoñez, P. (2013). El derecho a la educación intercultural bilingüe (EIB) de las comunidades campesinas y nativas del Perú. (Tesis de posgrado). Pontificia 
Universidad Católica del Perú: Lima. Recuperado de: http://tesis.pucp.edu. pe/repositorio/bitstream/handle/123456789/4806/ORDONEZ ROSALES PAOLA DERECHO EDUCACION.pdf?sequence=1\&isAllowed=y

Perú 21 (2017). Más de un millón de niños en el Perú hablan lenguas originarias. Recuperado de: https://peru21.pe/lima/millon-ninos-peru$\underline{\text { hablan-lenguas-originarias-77970 }}$

Pulido, Y. (2012). La etnoeducación bilingüe: logro político y desafío para las etnias. Lenguaje, pp. 231-254.

Romero, R. (2006). El orden interno y Derechos Humanos en el Perú. 1a Ed. Lima: Editorial San Marcos.

Santiesteban et al. (2008). Diagnóstico sociolingüístico para el fortalecimiento del quechua en comunidades campesinas de Canchis (Cusco). Lima: Tarea Asociación de Publicaciones Educativas.

Soto, J. (2008). El currículo intercultural bilingüe: la naturaleza humana integrada a su mundo cultural. $1^{\underline{a}}$ ed. Lima: Magisterio.

Tribunal Constitucional Peruano. Expediente N00091-2005-PA/TC. Recuperado de: http://www.tc.gob.pe/jurisprudencia/2006/00091-2005-AA.html

Tribunal Constitucional Peruano. Expediente $\mathrm{N}^{\circ}$ 0022-2009-PI/TC. Recuperado de: https:/ / www.tc.gob.pe/jurisprudencia/2010/00022-2009-AI.html

Tribunal Constitucional Peruano. Expediente $\mathrm{N}^{\circ}$ 00853-2015-PA/TC. Recuperado de: https:/ / tc.gob.pe/jurisprudencia/2017/00853-2015-AA.pdf

Tribunal Constitucional Peruano. Expediente $\mathrm{N}^{\circ}$ 00889-2017-PA/TC. Recuperado de: https://tc.gob.pe/jurisprudencia/2018/00889-2017-AA.pdf

Tribunal Constitucional Plurinacional Boliviano. Expediente N095202014-20-CEA. Recuperado de: https://buscador.tcpbolivia.bo/(S(m0yhtnark1eqfrjclu5kevde))/WfrExpedientes.aspx

Zavala, V. y Córdova, G. (2003). Volver al desafío: hacia una definición crítica de la educación intercultural en el Perú. Lima: Ministerio de Educación.

Fecha de recepción : : 31 de agosto de 2018

Fecha de aceptación : 15 de octubre 2018 